\title{
Sederoman sorg vir 'n donker, boeiende leeservaring
}

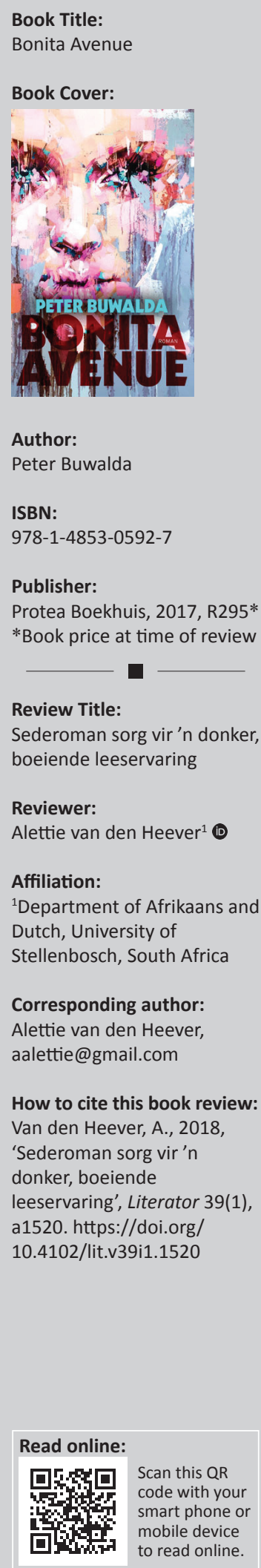

Bonita Avenue, die debuutroman van Peter Buwalda, volg die verval van die Sigerius-gesin, spesifiek die vaderfiguur Siem, teen die agtergrond van Enschede se vuurwerkramp. Laasgenoemde het op 13 Mei 2000 tot die dood van 23 mense en die verwoesting van 'n groot gedeelte van die Roombeekbuurt gelei (Vuurwerkramp, Gemeente Enschede s.d.).

Siem Sigerius was 'n belowende judoka toe hy in 1972 deur 'n bromponie getref is. Tydens agt maande in gips het hy sy wiskundige genialiteit ontdek, wat in 1986 tot 'n Fields-medalje gelei het. Hy is sedert 1993 rektor magnificus van die Tubantia Universiteit en word as die 'gloeiende middelpunt' en 'blakende son' van die kampus beskryf (bl. 8-9). Hy beklee'n soortgelyke, alhoewel meer dubbelsinnige plek in die lewens van die ander twee fokalisators, naamlik sy oudste stiefdogter en oogappel, Joni, en Aaron Bever, 'n fotograaf wat in 2000 Joni se kêrel en sakevennoot en Siem se vertroueling en judoskermmaat is. Alhoewel nie een van die drie fokalisators hulle ten tye van die ontploffing van SE Fireworks in Enschede bevind nie, vergelyk Joni later die vuurwerkfiasko met "n kraamkamer waarin nuwe rampe gebore word" (bl. 83). Die res van die Sigerius-gesin, die ma Tineke en die jonger suster Janis, is tot 'n groot mate onbewus van die gebeure wat tot die gesin se ondergang lei. In die 'kraamkamer' waarvan Joni praat, begin Siem egter die moontlikheid ondersoek dat Joni (en moontlik Aaron) 'n riskante internetwebtuiste bedryf, terwyl Aaron sy eerste ligte psigotiese episode beleef. Alhoewel Joni die beste daarvan afkom, wonder sy self later:

Het alles nie uiteindelik deur my toedoen verkeerd geloop nie? Was my gierige vertoonsug nie die oorsaak dat ons drie, wat soos 'n watermolekule met mekaar verbind was, uitmekaar gedryf het nie? (bl. 439)

Na afloop van die ramp bel Wilbert, Siem se vervreemde biologiese seun en 'n pas vrygelate misdadiger, om te hoor of Joni die ramp oorleef het. Hierdie kontak is nog een van die 'oerknalletjies' (bl. 83) wat met die vuurwerkramp gepaard gaan, omdat dit Siem en Joni met gebeure en bedrog konfronteer wat 11 jaar vantevore ook byna die gesin verwoes het. Terwyl al die hoofstukke waarin Siem fokaliseer in 2000 afspeel, speel die meeste van die hoofstukke waarin Joni en Aaron fokaliseer in 2008 af, met die fokus steeds op die gebeure van 2000.

Die temas wat in die roman aangeraak word, is in 'n groot mate tipies van die sederoman. Die vraag of die lot van 'n mens deur aangebore of aangeleerde faktore bepaal word (die natuuropvoedingdebat), staan sentraal. Ouerskap wat hiermee vervleg is, is ook een van die belangrike kwessies in die roman. Siem se wiskundige belangstelling in toevalligheid en die knoopteorie wys ook op ander invloede op die mens se lewenspad. Verder word geestesgesondheid en misdadigheid, sowel as die samelewing se hantering hiervan (bv. die invloed van gevangenisstraf op misdadigers) belig. Die kwessies van afsondering en eensaamheid word ondersoek in 2000 (toe nie eens al die karakters selfone gehad het nie) sowel as in 2008 (voordat sosiale media die sosiale landskap radikaal verander het). Die leser word op 'n subtiele wyse daaraan herinner dat die afsondering en valsheid eintlik nog altyd bestaan het, lank voor die sosiale media waarmee dit tans geassosieer word.

Bonita Avenue het in 2010 in Nederlands verskyn en is met die Anton Wachterprys, die Academica Debutanteprys, die Selexyz Debuutprys en die Tzumprys bekroon. Dit is ook vir nege ander pryse benoem (De Bezige Bij, s.d.). Die vertaalregte is in verskeie lande verkoop en Zandra Bezuidenhout vertaal die roman in Afrikaans. Die roman is deurlopend boeiend en by tye meesleurend. Die stemme en karakters is oortuigend en die verskillende karakters se perspektiewe wissel mekaar knap af. Die gevolg is dat die verhaal soos dit in 2000 en 2008 ontvou, stuk vir stuk belangrike inligting deurgee. Genoeg inligting word egter weerhou sodat die leser steeds aan die einde belangrike onthullings kan verwag. Die struktuur van die roman sorg vir 'n uiters bevredigende leeservaring. Die lang terugflitse (in sommige gevalle terugflitse binne-in terugflitse)

Copyright: (C) 2018. The Authors. Licensee: AOSIS. This work is licensed under the Creative Commons Attribution License. 
stel wel op sommige plekke hoë eise aan die leser. Dit is veral die geval waar daar in terugflitse van die verlede tyd na die teenwoordige tyd oorgeskakel word en die oorgang na die hede van die verhaal dan nie duidelik aangedui word nie. Verder word daar verwarrende inligting oor die tydlyn rakende Joni se geboorte en die verloop van Tineke en Siem se verhouding gegee. Dit blyk byvoorbeeld dat Tineke en Joni in 1972 by die beseerde Siem gaan kuier het, maar in 1996 is Joni slegs 20 jaar oud.

Bonita Avenue sal die aandag van diegene trek wat van familiedramas en sielkundige rillers hou en dit behoort ook tot lesers te spreek wat van boeiende wêreldliteratuur hou. Die roman bied 'n uiters genuanseerde perspektief op die menslike situasie en die wyse waarop opvoeding, gene, toeval, besluite, (die onderdrukking van) begeertes, sowel as idees rondom reg en verkeerd, en geluk en skande 'n mens kan vorm en tot 'n val kan bring.

\section{Literatuurverwysings}

Vuurwerkramp, Gemeente Enschede, s.d., Vuurwerkramp, besigtig op 29 Maart 2018, vanaf http://www.vuurwerkramp.enschede.nl/

De Bezige Bij, s.d., Peter Buwalda-biografie, besigtig op 29 Maart 2018, vanaf https:// www.debezigebij.nl/auteurs/peter-buwalda/ 